\title{
IMPLEMENTATION USING SOCIAL MEDIA OPTIMIZATION (SMO) FOR INTERNET MARKETING ON RUMAHDANPROPERTI.COM
}

\author{
David Chandra and Hoga Saragih \\ Fakultas Ilmu Komputer, Universitas Bina Nusantara, Jl. Kebon Jeruk Raya No. 27, Kebon Jeruk, Jakarta \\ Barat 11530, Indonesia \\ E-mail: david.chan.ming@gmail.com
}

\begin{abstract}
Lately, social media like Facebook become one of the methods to do marketing of products and online services. Social Media Optimization (SMO) is a marketing method that is now being developed by many companies in the field of internet marketing. The purpose of this study is the implementation using social media optimization (SMO) on the rumahdanproperti.com website. Rumahdanproperti.com is the website which is the largest property advertising portal in Indonesia which focuses on online business. The research will implement the SMO method using Facebook as a means of product introductions and analyze the use of existing Facebook features in response to rumahdanproperti.com ads. The research method used quantitative analysis and software analysis to measure advertising response to the features used on rumahdanproperti.com facebook. In conducting the quantitative analysis, researcher used questionnaires to obtain data from respondents who are members of this rumahdanproperti.com Facebook. The result of this implementation of the SMO is expected to support companies in introducing their brands to the public. The conclusion of this research, feed and discussion feature on Facebook have an influence on response of rumahdanproperti.com ads.
\end{abstract}

Keywords: internet marketing,social media optimization

\begin{abstract}
Abstrak
Akhir-akhir ini, media sosial seperti Facebook menjadi salah satu metode untuk melakukan pemasaran produk dan layanan online. Social Media Optimization (SMO) adalah sebuah metode pemasaran yang kini banyak dikembangkan oleh banyak perusahaan di bidang internet marketing. Tujuan dari penelitian ini adalah implementasi menggunakan SMO pada website rumahdanproperti.com. Rumahdanproperti.com adalah website yang menjadi portal iklan properti terbesar di Indonesia yang berfokus pada bisnis online. Penelitian ini akan menerapkan metode SMO menggunakan Facebook sebagai sarana pengenalan produk dan menganalisis penggunaan fitur Facebook yang ada dalam menanggapi iklan rumahdanproperti.com. Metode penelitian menggunakan analisis kuantitatif dan analisis perangkat lunak untuk mengukur respons iklan untuk fitur yang digunakan pada facebook rumahdanproperti.com. Dalam melakukan analisis kuantitatif, peneliti menggunakan kuesioner untuk mendapatkan data dari responden yang menjadi anggota facebook rumahdanproperti.com ini. Hasil dari pelaksanaan SMO diharapkan untuk mendukung perusahaan dalam memperkenalkan merek mereka kepada publik. Kesimpulan dari penelitian ini fitur, pakan dan diskusi di Facebook memiliki pengaruh pada respon iklan rumahdanproperti.com.
\end{abstract}

Kata Kunci: internet marketing,optimisasi media sosial

\section{Introduction}

Internet evolution has brought the media to the public. Interactive nature of Internet marketing in delivering a fast response is the hallmarks of advertising on the internet. Advertising via the internet does not only refer to marketing on the internet but also includes marketing through email and wireless media. Logged Internet growth in Indonesia is quite drastic [1], according internetworldstats.com, Internet users in Indonesia is currently (2010) reached 30 million users. In
2007, the number of Internet users reached 20 million registered users, this number increased by $50 \%$ until the year 2010. Indonesia, including five countries with the largest Internet users in Asia in 2009 according to internetworldstats.com.

The emergence of Web 2.0 in 2004 which is the second generation of web-based services such as Wikipedia, social networking sites and others that emphasize online collaboration and inter-user view (O'Reilly, 2005). Web 2.0 evolution and social networking sites like Facebook, making many advertisers move to online media. 
Especially after the introduction of social networking sites are much in demand and the intensity was visited by its members. Facebook is being rapidly adopted by most of the global community from various backgrounds, ages and gender. Print and electronic advertising are medium that is widely used, but over the increasingly high operating costs due to rising prices and global crises that occur repeatedly, then advertise the Internet became an alternative choice for advertisers who want efficient yet precise purpose of the ad. At first, marketers assess online media is only the addition of existing media such as radio, television and print media [2].

Social media like Facebook has become a coveted media by every marketer to be targeted in the marketing of their products. According to statistics Facebook users around the world on checkfacebook.com [3], Indonesia ranks third largest in the world after the U.S.and the UKwith 36 million users, so marketing of products will quickly spread to the users of this country.

In modern age, digital media technology like internet and cell phones are favored by the people from young to old age. Internet media and mobile phones are currently one of the alternatives are cheaper and easier to search for sources of information consumers need. A survey [4] from TNS Indonesia with yahoo (2009) said there were about $64 \%$ of Internet users in Indonesia is dominated by teens aged 15-19. They used the internet to check email services $(59 \%)$, instant messaging (59\%) and social networking (58\%).

TABLE I

FACEBOOK GROWING

FACEBOOK GROWING
\begin{tabular}{|l|l|l|}
\hline \multicolumn{3}{|c|}{10 Largest Countries } \\
\hline 1. & United States & 149.327 .060 \\
\hline 2. & Indonesia & 36.699 .540 \\
\hline 3. & United Kingdom & 29.500 .800 \\
\hline 4. & Turkey & 27.981 .400 \\
\hline 5. & India & 26.626 .040 \\
\hline 6. & Mexico & 24.810 .220 \\
\hline 7. & Philippines & 24.501 .880 \\
\hline 8. & France & 21.736 .080 \\
\hline 9. & Italy & 19.631 .700 \\
\hline 10. & Brazil & 19.044 .060 \\
\hline
\end{tabular}

Internet evolution provides another influence in the field of internet marketing where even become a new tool for consumers in searching for products or services, whether the information provided by the seller as well as information provided by others. World of internet allows everyone to give their personal opinion about a product and services in accordance with the experience or information received previously either positive or negative information.
In digital era, consumers can find information desired product or service more widely because of information obtained in the internet world can be a reference that can be trusted because of the reviews from users of products or services. Thanks to Web 2.0 technology, the consumer perspective is no longer fixated on information from the seller/marketer of products but also from the numerous reviews undertaken other users.

The views of consumers in selecting products and manufacturers that produce it affect the desire and the consumer's decision to buy a product or service. These views were shaped by information received from a reliable consumer media.

Internet and social media now have formed a community to interact with each other, exchange opinions and provide useful information to the public. The amount of great information on social media is available in blogs, sharing sites knowledge sharing, online gaming, social networking, news groups, chat rooms, ebusinesses, etc [5].

Facebook is one social media that using web 2.0 technology and famous because of the freedom of expression and opinion expressed by any member. Through the features provided web 2.0, Facebook can be a medium to provide a review of a product or service to consumers because the news spread very quickly and proved to be effective. Social media is widely used by $79 \%$ on the 100 best companies in the world.

According information above, the researchers want to conduct an analysis method of Social Media Optimization (SMO) as an internet marketing techniques in addition to SEO. The questions is using SMO through Facebook in helping rumahdanproperti.com in introducing their products or services to the public; and are there features on Facebook can support Facebook as Social Media Optimization.

Purpose this research is to analyze Facebook features that used frequently to respond "rumahdanproperti" ads. The results of this analysis can provide companies using Social Media Optimization methods to get maximum results in the development of advertising rumahdanproperti.com.

Social media marketing is the latest addition in the world of marketing which is used to establish communication on an integrated marketing plan. Unified communications is a principle of organization that is connected with their target market. [6] Includes the promotion of integrated marketing communications, advertising, personal selling, public relations, direct marketing and sales promotion. 
Social media developments affect the way organizations communicate. The emergence of Web 2.0, allows people to build business and social relationships, share information and collaborate on projects online.

Marketing through social media usually focus their efforts on creating content that attracts attention and encourages readers to share with their social network. Social media becomes a platform that is easily accessible by anyone with the Internet, enabling companies to increase their brand awareness and facilitate conversations with customers.

Social media marketing is also known as SMO (Social Media Optimizer) by providing additional pathways to support customers and get customers. Key factors that ensure the company's success is its relevance to the customer, the value assigned them and the strength of the foundations that have been built.

There are two categories on SMO. First, social media features that are added to the content itself such as RSS feed social news, key sharing, user ratings and polling tool. Second, promotion of social media activity in addition to the content being promoted, including blogging, commenting on blogs, discussion and status update on social networking.

\begin{tabular}{|c|}
\hline $\begin{array}{l}\text { Social Networking Site Activities of US Social } \\
\text { Network Users, May } 2009 \text { (\% of respondents) }\end{array}$ \\
\hline Became a fan/follower of some other company/brand \\
\hline 529 \\
\hline Said something good about a brand/company \\
\hline $46 \%$ \\
\hline Said something bad about a brand/company \\
\hline $23 \%$ \\
\hline Promoted some other company/brand \\
\hline $18 \%$ \\
\hline Promoted your own business \\
\hline $12 \%$ \\
\hline $\begin{array}{l}\text { Note: } n=1,000 \\
\text { Source: Anderson Analytics, "Social Network Service (SNS) A\&U Profiler," } \\
\text { provided to eMarketer, July } 13,2009\end{array}$ \\
\hline
\end{tabular}

Figure 1. Social media survey at UK.

SMO connected as a technique for visual marketing of mouth instead of through friends or family but through networking in social bookmarking, video and photo sharing sites. SMO is often used to encourage a community of related sites that allow for sound business.

According to [7] Danny Sullivan (2006), SMO first used by [8] Rohit Bhargava's 5 rules that describe the SMO as creating content that can be shared, sharing facility, appreciate the involvement, encourage the mash up, and share content proactively.

According to [9] the Anderson Analytics survey (May 2009), 52\% of users of social media are fan or follower in a company or brand, $46 \%$ say it is good to the brand or the company on social media websites, only $23 \%$ who say negative things, as shown in figure 1.

In December 2008, a survey conducted by Marketing Sherpa in which $92 \%$ of social media affects brand reputation and $91 \%$ said the increase brand awareness, as shown in figure 2.

\section{Methodology}

There are five stages in this research method. The first stage, the authors analyze the problems that occurred in rumahdanproperti.com and assign several problems to be analyzed and a solution found solving the problem.

The second stage is to conduct studies in the literature where the authors conducted a study to find the source of literature through books, journals, and websites on the internet. Information-information collected used as a theoretical foundation in the preparation of this thesis in order to be justified scientifically.

The third stage is the researchers will conduct analysis using quantitative methods and analysis using the application that is smartest at. In quantitative analysis the researchers will deploy the questionnaire. Analysis using the software will begin to be analyzed on January 1, 2011 to May 1, 2011 to support the results of this study.

The fourth stage is the result of analysis, at this stage the results of quantitative analysis and analysis software were combined to obtain the desired results and complement each other.

The fifth stage is the last stage in this study where the outcome of the discussion is concluded for answers to problems that occur along with suggestions in its application.

This study will use two kinds of variables: the dependent variable and the independent variable. Dependent variable used in this study is feature as an influence on Facebook internet marketing. 
US Social Media Marketing Professionals Who Believe
Social Media Marketing Is an Effective Branding
Strategy, December 2008 (\% of respondents)

Somewhat Not

\begin{tabular}{lccc}
\hline & $\begin{array}{c}\text { Very } \\
\text { effective }\end{array}$ & $\begin{array}{c}\text { Somewhat } \\
\text { effective }\end{array}$ & $\begin{array}{c}\text { Not } \\
\text { effective }\end{array}$ \\
\hline Influence brand reputation & $39 \%$ & $53 \%$ & $8 \%$ \\
\hline Increase brand awareness & $37 \%$ & $54 \%$ & $9 \%$ \\
\hline Improve search engine rankings & $38 \%$ & $49 \%$ & $13 \%$ \\
\hline Increase Website traffic & $33 \%$ & $55 \%$ & $13 \%$ \\
\hline Generate leads & $17 \%$ & $48 \%$ & $35 \%$ \\
\hline Improve internal communications & $17 \%$ & $39 \%$ & $45 \%$ \\
\hline Increase online sales & $13 \%$ & $41 \%$ & $46 \%$ \\
\hline
\end{tabular}

Note: $n=1,886$

Source: MarketingSherpa, "Social Media Marketing and PR: Benchmarks and Best Practices," April 6, 2009

$105540 \quad$ www.eMarketer.com

Figure 2. Marketing Sherpa Survey.

TABLE II

VALIDITY TEST

\begin{tabular}{|c|c|c|c|c|c|}
\hline No & $\begin{array}{l}\text { Scale Mean if } \\
\text { Item Deleted }\end{array}$ & $\begin{array}{l}\text { Scale Variance if } \\
\text { Item Deleted }\end{array}$ & $\begin{array}{c}\text { Corrected Item-Total } \\
\text { Correlation }\end{array}$ & $\begin{array}{c}\text { Squared Multiple } \\
\text { Correlation }\end{array}$ & $\begin{array}{c}\text { Cronbach's Alpha if } \\
\text { Item Deleted }\end{array}$ \\
\hline Q5 & 10.29 & 7.790 & .600 & .400 & .771 \\
\hline Q6 & 10.16 & 6.716 & .607 & .397 & .767 \\
\hline Q7 & 10.00 & 6.616 & .728 & .550 & .725 \\
\hline Q8 & 9.81 & 7.020 & .582 & .380 & .774 \\
\hline Q9 & 10.01 & 8.070 & .470 & .280 & .804 \\
\hline Q10 & 11.55 & 7.185 & .373 & .171 & .787 \\
\hline Q11 & 11.25 & 5.589 & .535 & .374 & .749 \\
\hline Q12 & 11.33 & 5.764 & .778 & .649 & .663 \\
\hline Q13 & 11.15 & 6.295 & .640 & .516 & .710 \\
\hline Q14 & 10.60 & 6.178 & .492 & .269 & .757 \\
\hline Q15 & 10.38 & 7.110 & .596 & .419 & .750 \\
\hline Q16 & 10.07 & 5.995 & .655 & .472 & .727 \\
\hline Q17 & 10.07 & 6.396 & .704 & .510 & .712 \\
\hline Q18 & 9.85 & 6.943 & .515 & .358 & .774 \\
\hline Q19 & 10.09 & 7.600 & .419 & .243 & .800 \\
\hline Q20 & 10.64 & 5.971 & .368 & .077 & .773 \\
\hline Q21 & 10.45 & 4.677 & .514 & .273 & .697 \\
\hline Q22 & 10.19 & 4.434 & .685 & .512 & .626 \\
\hline Q23 & 10.21 & 4.493 & .575 & .377 & .671 \\
\hline Q24 & 10.25 & 5.364 & .518 & .339 & .698 \\
\hline Q25 & 10.39 & 7.999 & .605 & .404 & .784 \\
\hline Q26 & 10.24 & 6.888 & .621 & .412 & .778 \\
\hline Q27 & 10.07 & 6.815 & .740 & .571 & .738 \\
\hline Q28 & 9.91 & 7.158 & .601 & .413 & .783 \\
\hline Q29 & 10.12 & 8.211 & .489 & .305 & .812 \\
\hline Q30 & 10.36 & 8.301 & .574 & .375 & .803 \\
\hline Q31 & 10.49 & 7.230 & .545 & .323 & .811 \\
\hline Q32 & 10.05 & 6.512 & .761 & .618 & .740 \\
\hline Q33 & 9.95 & 6.505 & .689 & .480 & .765 \\
\hline Q34 & 10.10 & 8.092 & .550 & .402 & .806 \\
\hline
\end{tabular}

Independent variables used in this study consisted of existing features on the Facebook such as notes, feeds, event, discussion and image. Samples will be taken 285 peoples with a Slovin method of 1000 members' rumahdanproperti.com facebook as shown on table II. Statements made in the questionnaire have a choice of 1-4 scale using a Likert scale that helps characteristics statement.
One important element in determining the value of the scale is the validity and reliability. Scale of 1-4 is used in this questionnaire because the researcher requires positive and negative responses and does not require a neutral response, as shown on table III. The following hypotheses have been formulated:

H1: using note feature frequently, have a great ads response on Facebook 
H2: using feed feature frequently, have a great ads response on Facebook.

H3: using event feature frequently, have a great ads response on Facebook.

H4: using discussion feature frequently, have a great ads response on Facebook.

H5: using image feature frequently, have a great ads response on Facebook.

Based on validity test of the independent variables note (table IV), feed (table V), event (table VI), discussion (table VII), and image (table VIII), summed up the question on the corrected item total correlation above 0.3 .

In the reliability test [10], the tables III-VIII show the value of Cronbach's alpha above 0 , so it can be concluded that the scale of measurement above have good reliability.

TABLE III

RELIABILITY TEST - RESPONSE ADS ON FACEBOOK

\begin{tabular}{ccc}
\hline $\begin{array}{c}\text { Cronbach's } \\
\text { Alpha }\end{array}$ & $\begin{array}{c}\text { Cronbach's Alpha Based } \\
\text { on Standardized Items }\end{array}$ & N of items \\
\hline .807 & .809 & 5 \\
\hline & $\begin{array}{c}\text { TABLE IV } \\
\text { RELIABILITY TEST - NOTE }\end{array}$ \\
\hline $\begin{array}{c}\text { Cronbach's Alpha } \\
\text { Alpha }\end{array}$ & $\begin{array}{c}\text { Based on Standardized } \\
\text { Items }\end{array}$ & N of items \\
\hline .777 & .786 & 5 \\
\hline
\end{tabular}

TABLE V

RELIABILITY TEST - FEED

\begin{tabular}{ccc}
\hline $\begin{array}{c}\text { Cronbach's } \\
\text { Alpha }\end{array}$ & $\begin{array}{c}\text { Cronbach's Alpha } \\
\text { Based on Standardized } \\
\text { Items }\end{array}$ & N of items \\
\hline .794 & .794 & 5 \\
\hline
\end{tabular}

TABLE VI

RELIABILITY TEST - EVENT

\begin{tabular}{ccc}
\hline $\begin{array}{c}\text { Cronbach's } \\
\text { Alpha }\end{array}$ & $\begin{array}{c}\text { Cronbach's Alpha } \\
\text { Based on Standardized } \\
\text { Items }\end{array}$ & N of items \\
\hline .743 & .740 & 5 \\
\hline
\end{tabular}

TABLE VII

\begin{tabular}{ccc}
\multicolumn{3}{c}{ RELIABILITY TEST - DISCUSSION } \\
\hline $\begin{array}{c}\text { Cronbach's } \\
\text { Alpha }\end{array}$ & $\begin{array}{c}\text { Cronbach's Alpha } \\
\text { Based on Standardized } \\
\text { Items }\end{array}$ & N of items \\
\hline .816 & .818 & 5 \\
\hline
\end{tabular}

TABLE VIII

RELIABILITY TEST - IMAGE

\begin{tabular}{ccc}
\hline $\begin{array}{c}\text { Cronbach's } \\
\text { Alpha }\end{array}$ & $\begin{array}{c}\text { Cronbach's Alpha } \\
\text { Based on Standardized } \\
\text { Items }\end{array}$ & N of items \\
\hline .822 & .825 & 5 \\
\hline
\end{tabular}

The following are the results of the analysis of Entered Variables (table IX) and Model Summary (table X). Variables Entered table shows that no variable excluded (removed) or in other words, independent variables included in the calculation of regression. $\mathrm{R}$ figure of 0.970 indicates an independent variable has a strong relationship, $\mathrm{R}>0.5$. $\mathrm{R}$ square figures for 0.940 indicate "rumahdanproperti" Response advertising on Facebook can be influenced by the notes, feeds, event, discussion and image. While other factors influenced the rest of 0.060 .

TABLE IX

ENTERED VARIABLE

\begin{tabular}{llll}
\hline \multicolumn{1}{c}{ Model } & $\begin{array}{l}\text { Variables } \\
\text { Entered }\end{array}$ & $\begin{array}{c}\text { Variables } \\
\text { Removed }\end{array}$ & Method \\
\hline 1 & Discussion, & & Enter \\
& Feed, Note, & & \\
Event, Image & & \\
\multicolumn{3}{c}{ a. All requested variables entered } \\
b. Dependent Variable : Respon Iklan &
\end{tabular}

TABLE X

MODEL SUMMARY

\begin{tabular}{|c|c|c|c|c|c|}
\hline $\begin{array}{c}\text { Model } \\
\mid\end{array}$ & $\mathrm{R}$ & $\begin{array}{c}\mathrm{R} \\
\text { Square }\end{array}$ & $\begin{array}{l}\text { Adjuste } \\
\text { d R } \\
\text { Square }\end{array}$ & $\begin{array}{l}\text { Std. } \\
\text { Error } \\
\text { of } \\
\text { the } \\
\text { Esti } \\
\text { mate }\end{array}$ & $\begin{array}{l}\text { Durbin- } \\
\text { Watson }\end{array}$ \\
\hline 1 & $.970^{\mathrm{a}}$ & .940 & .939 & .810 & .931 \\
\hline
\end{tabular}

a. Predictors : (Constant), Discussion, Feed, Note, Event, Image

b. Dependent Variable : Respon Iklan

Based on table XI, in the variable note, can be seen that the value of Sig. $=0.302>$ value $\alpha=$ 0.05 , so it can inferred independent variable note there is no significant level, then $\mathrm{H} 0$ is accepted.

In the variable feed, can be seen that the value of Sig. $=0.005<\alpha=0.05$ value, so it can be concluded the independent variables had significant levels of feed then $\mathrm{H} 0$ is rejected.

In the event variable, can be seen that the value of Sig. $=0.029>$ value $\alpha=0.05$, so it can be concluded the independent variables there is no significant level event then $\mathrm{H} 0$ is accepted.

In the discussion of variables, can be seen that the value of Sig. $=0.000<\alpha=0.05$ value, so it can be concluded the independent variables had significant levels of discussion then $\mathrm{HO}$ is rejected.

In the variable image, can be seen that the value of Sig. $=0.207>$ value $\alpha=0.05$, so it can inferred independent variable image no significant levels then $\mathrm{H} 0$ is accepted.

From the Anova test as shown in table XI, get the F count is 879,852 with a significant level of 0000. Therefore significant (0000) is much smaller than 0.05 , then the regression model can be used to predict the response "rumahdanproperti" ads on Facebook.

In software analysis using smarterstats applications, researcher did not conduct an analysis to see Facebook users response to the features of note, feeds, event, image and 
TABLE XI

COEFFICIENT INDEPENDENT VARIABLE TABLE

\begin{tabular}{|c|c|c|c|c|c|}
\hline \multirow[t]{2}{*}{ Model } & \multicolumn{2}{|c|}{ Unstandardized Coefficients } & \multirow{2}{*}{$\begin{array}{c}\text { dardized Coefficients } \\
\text { Beta }\end{array}$} & \multirow[t]{2}{*}{$\mathrm{t}$} & \multirow[t]{2}{*}{ Sig. } \\
\hline & $\mathrm{B}$ & Std.Error & & & \\
\hline (Constant) & -.032 & .302 & & -.107 & .915 \\
\hline Note & -.018 & .017 & -.016 & -1.034 & .302 \\
\hline Feed & .080 & .028 & .078 & 2.831 & .005 \\
\hline Event & .073 & .033 & .060 & 2.195 & .029 \\
\hline Discussion & .828 & .034 & .839 & 24.659 & .000 \\
\hline Image & .030 & .024 & .030 & 1.264 & .207 \\
\hline
\end{tabular}

a. Dependent Variable : Respon Iklan

TABLE XII

ANOVA TEST

\begin{tabular}{llllll}
\hline & Model & \multicolumn{1}{c}{ Sum of Squares } & df & Mean Square & F \\
\hline $1 \quad$ Regresion & 2883.072 & 5 & 576.614 & 879.852 & $.000^{\mathrm{a}}$ \\
Residual & 182.844 & 279 & .655 & \\
Total & 3065.916 & 284 & & \\
\hline
\end{tabular}

discussion but it reinforces the reason to wear Facebook as a media application of the SMO (Social Media Optimization) to support the use of SEO methods.

Figure 3 shows the rumahdanproperti.com ads referenced by several websites including a Facebook. This statistic is a statistic based on the daily website visitors' rumahdanproperti.com referring website. With the SMO using Facebook to support the SEO methods that have been running so it might be expected both of these methods can yield maximum results in spreading the ads on the website rumahdanproperti.com and increase existing advertising response.

\section{Result and Analysis}

After doing the above research, researcher will design the IT Strategic Planning for the website rumahdanproperti.com use Facebook as a method of strategic IT planning.

Researchers will implement the RSS feature on the website because it feeds on Facebook rumahdanproperti.com affect the response to advertisements on Facebook, so if rumahdanproperti.com using RSS and the RSS is posted on blogs and consumer websites, can increase the traffic on SEO.

Based on questionnaire deployed, features discussion applied by rumahdanproperti.com quite affecting user response to these ads Facebook so that researcher would suggest that the website can be paired with an online forum for example, can be accessed via www.rumahdanproperti.com/ forum where the content of the forum is made to answer all questions from consumers and all related property. The forum also contributed to the traffic on the website so that it strongly supports the SEO methods.
In addition to features that can be optimized through Facebook to support ongoing SEO method, Facebook can also be used as feedback, customer relationship, and review.

Facebook can be used to expand the network or community and market products directly to consumers. Companies also need feedback in the form of positive and negative. In the positive form can enhance the reputation of a brand that is owned by the company. In the negative form can be used as consideration of the nature or suggestions can be developed so that improvement scan be done to repair.

Facebook can be a bridge that links between businesses and consumers so that the relationship between the two parties can be maintained properly. Given that good customer relationship system can help companies to have more effective relationships with consumers e.g. in the case increase customer satisfaction, easy to share information, increase sales, and identify customers.

Using Facebook as a means of promotion and customer relationship, Facebook also expected to be used as a means to review a product using viral marketing, or known by word of mouth marketing, with a commentary about a given product on Facebook rumahdanproperti.com can make other consumers think to buy the product or used it for comparison.

\section{Conclusion}

Based on the results of research on the analysis of the use of social media optimization (SMO) as an internet marketing rumahdanproperti.com in IT strategic planning, it can be summed up as follows. First, Feed and Discussion Features affect the response to the ads on Facebook rumahdanproperti.com. 


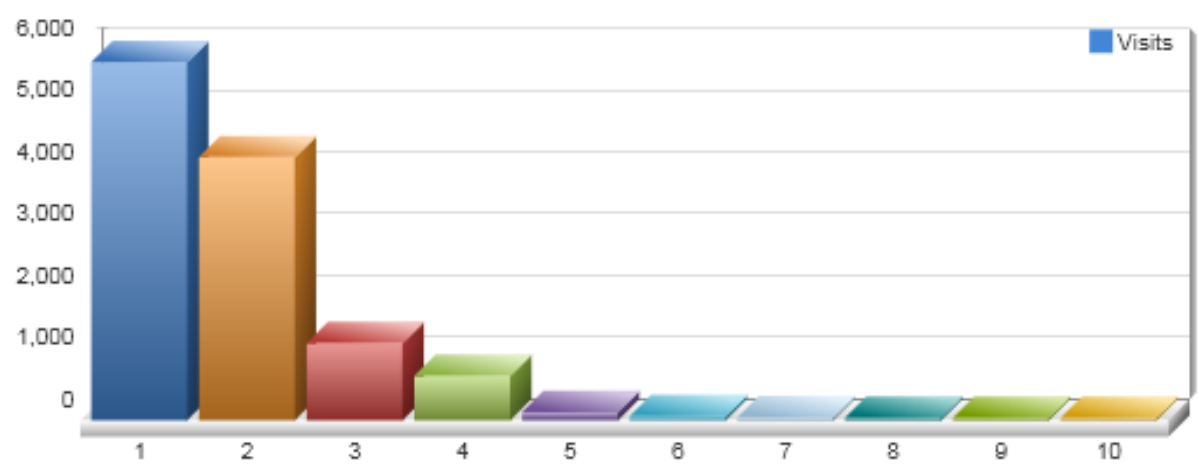

\begin{tabular}{llc} 
Rank & Host & Visits \\
\hline 1 & No Referrer (bookmark or direct-entry) & 5,795 \\
\hline 2 & Www.google.co.id & 4,259 \\
\hline 3 & www. rumahdanproperti.com & 1,252 \\
\hline 4 & Www.google.com & 725 \\
\hline 5 & www.kaskus.us & 137 \\
\hline 6 & id.search.yahoo.com & 69 \\
\hline 7 & Www.google.com.sg & 51 \\
\hline 8 & search.yahoo.com & 45 \\
\hline 9 & www.bing.com & 44 \\
\hline 10 & www. facebook.com & 41 \\
\hline
\end{tabular}

Figure 3. Smarterstats software analysis.

Because feed features quite affecting user response to ads on rumahdanproperti.com then researcher suggest that rumahdanproperti.com website has a feature so users can subscribe to the feed from the feed feature on the website rumahdanproperti.com. Feed on the website is a pull technology where the content of the website is pulled and sent to the user. A web feed format usually has an RSS (Really Simple Syndication) and Atom. News on the website usually comes from the web feeds, but feeds are also used to deliver structured information that supports the search results (search engines).

In other words, existing technology such as feed on Facebook we can apply also on Facebook so it can support as well rumahdanproperti.com SEO methods that have previously been run by the website rumahdanproperti.com. Because the discussion features affect the user response to advertisements on Facebook rumahdanproperti.com then researcher suggest discussion feature can be applied to websites such rumahdanproperti.com use online forums to support the development of rumahdanproperti.com website. Topics that are generally made on an online forum to attract Internet users, especially in terms of searches on search engines (search engines). Features an online forum itself had already been implemented by a type of website it will be very good if an online forum can be applied as a complementary tool and an introduction to the wider community rumahdanproperti.com. Second, more respondents choose to agree to use feed, images, discussion on Facebook rumahdanproperti.com. Based on the results of research using the features on Facebook, the researcher would recommend to use of this third feature (feeds, images, and discussion) in order to always be applied to any existing ads on Facebook rumahdanproperti.com because these features are more frequently used by the users of Facebook so that the usage habits of this feature may encourage them to at least see the ads on Facebook rumahdanproperti.com before finally deciding to buy the products offered.

Third, from Smarterstats software analysis, Facebook is one of websites that gives a reference to the ads from facebook rumahdanproperti.com. Using SMO through Facebook is very supportive of proven SEO methods of analysis software that says Facebook is one of 10 websites that contribute to the development of advertising on the website rumahdanproperti.com

\section{Acknowledgement}

The author would like to thank to Dr. Hoga Saragih, ST., MT., As my mentors who have 
helped the compilation of this paper and provide feedback and suggestions until the completion of this paper made.

\section{Reference}

[1] Stephen D. Rapport, Journal of Advertising Research, p.137, 2007.

[2] S. Staab, P.Domingos, P.Mika, J.Golbeck, L.Ding, T. Finin, A.Joshi, A.Nowak, \&R.R. Vallacher, "Social Networks Applied," IEEE Intelligent Systems, vol. 20, pp. 80-93, 2005.

[3] W. Glynn Mangold \& David J. Faulds, "Social media : The new hybrid element of the promotion mix", Business Horizons, vol. 52, pp. 357-365, 2009.

[4] Internet World Stat, Internet Users And Population Statistics For Asia, Internet World Stats,

http://www.internetwoeldstats.com/stats3.ht m\#asia, 2010, retrieved August 4, 2010.
[5] Check facebook, 10 Largest Country and Population Statistics, Check facebook, http://www.checkfacebook.com/, 2011, retrieved October 5, 2011.

[6] Survey TNS Indonesia bersama Yahoo, www.admaxnetwork.com/download/news/ NetIndexIndonesiaHighlights.pdf

[7] Danny Sullivan, Social Media Optimization: It's Like SEO, For Social Sites, blog.searchenginewatch.com, 2006, retrieved November 23, 2008.

[8] E-marketer http://www.emarketer.com/Article.aspx?R=1 07252

[9] Rohit Bhargava, The 5 NEW Rules of Social Media Optimization (SMO),

rohitbhargava.typepad.com, 2010, retrieved August 10, 2010.

[10] J.C. Nunnally \& I.H. Bernstein, Psychometric Theory, $3^{\text {rd }}$ ed, McGraw Hill, New York, 1994. 